\title{
Variables Affecting Congregation's Trust and Mosque Organizational Performance
}

\author{
Munir Is'adi ${ }^{*}$, Ahmad Roziq ${ }^{2}$, Muhammad Miqdad ${ }^{3}$, Novi puspitasari ${ }^{4}$ \\ ${ }^{1} \mathrm{KH}$. Achmad Siddiq State Islamic University of Jember, University of Jember, Jl. Kalimantan No. 37 Tegal Boto Campus \\ Jember, East Java, Indonesia \\ 2,3,4 University of Jember, Jl. Kalimantan No. 37 Tegal Boto Campus Jember, East Java, Indonesia \\ Email : munirisadi@gmail.com¹, ahmadroziq.feb@unej.ac.id², miqdad.feb@unej.ac.id³ ${ }^{3}$,novipuspitasari@unej.ac.id ${ }^{4}$ \\ * Corresponding Author
}

Received: 22.11.2021 Accepted: 14.12.2021 Published: 02.02.2022 DOI: 10.47750/QAS/23.186.11

\begin{abstract}
Mosque is a non-profit community organization, where the purpose of its establishment is not to seek profit, so this objective makes it different from commercial organizations. "Takmir" (manager of a mosque)as a manager, has the responsibility and trust of the congregation. This was explanatory research with a quantitative approach. The level of a good trust can be improved by consinously improving the quality of variabels so that the mosque organization managed can run properly and correctly and the congregation's trust can be achived. When the good mosque governance concept with the principles, internal control and services are used properly, it will be able to improve organization performance. Congregation's trust in the takmir to improve the performance of the mosque's organization can be achieved by increasing the ability, kindness and integrity of the takmir. The congregation's trust in the takmir will affect its intensity in participating in activities organized by the mosque, in which it will directly affect the performance of the mosque's organization. For Next research, it is recommended to add a variable of the concept of leadership from organizational managers. The participation variable from the congregation and the community, and professional variables, Professional someone will have a positive and significant impact on the quality of work.
\end{abstract}

Keywords: Good mosque governance, internal control, Service Religious organizations affiliation Trust, Organizational Performance

\section{Introduction}

Considering its very strategic function, it is truly necessary to have an optimal development and management concept that can provide more benefits to the congregation. The development in question is both in the physical and nonphysical fields. As a non-profit community organization, where the purpose of its establishment is not to seek profit, so this objective makes it different from commercial organizations. The management of mosque resources is usually carried out by "Takmir" (manager of a mosque). As a non-profit organization, its financial resources come from the congregation or donors. Takmir as a manager, has the responsibility and trust of the congregation, thus he is responsible for managing finances properly. As a non-profit organization, a mosque, which can be interpreted as an institution, organization or institution, does not aim to seek and take profit in managing its organization. Material profit is not the only indicator of success for nonprofit organizations, but it does not mean that the nonprofit organizations are not allowed to earn profit. Profits earned from activities carried out by non-profit organizations are returned for the financing and interests of the organization. Based on the Institute of Indonesia Chartered Accountants or IAI (2018) in ISAK Number 35, non-profit organization resources are obtained from donations or contributions from members of the organization and other donors who provide grant selflessly.

Is'adi (2017) argues that there are several reasons the congregations are inactive to participate in mosque activities. First, the mosque built magnificently is not well maintained. It can be seen from the dirty condition of the place so that people are reluctant to pray at the mosque. Second, the administrators still often accumulate money or current assets, meanwhile there are many basic things require financing. Next, lack of transparency in the management of finance or in organizing activities; Then, ones involved in activities, such as imam (man leading prayers in mosque) is not good enough or sometimes he does not know the condition of the congregation; Last, poor services provided for congregations so that they cannot acquire deeper knowledge. At the beginning of 2019, there was a virus that we know as Covid-19. The whole world has been impacted by this virus. The impact was not only on the economic and transportation sectors, but the impact was also found on all sectors of human life. This also affected the management of worship places where there was a restriction to make crowd according to Regulation of Government Number 21 of 2020 on PSBB (Large-Scale Social Restrictions) to deal with COVID-19 (2020). Therefore, worship places have been left empty.

In addition to the above problems, according to Affifudin and Nabihah, (2010) there is a problem in internal control that has not been maximized within the mosque organization which causes a poor financial reporting system or non-standard financial reports. They only make reports of financial income and expenses. Takmir often carries out his duties not in accordance with the plan. In fact, to manage a successful organization, a proper management control system is required (Sanusi et al. 2015). Besides, there are still mosque types groupings based on the organization adopted by the takmir. 
To organize an activity, a large amount of funds is required. So, all administrators or takmir must maximize all their potential to meet their needs. Congregation's trust which is the basis of all activities must be maintained. Mayer, Davis, and Schoorman (1995) conveyed that integrity, abilities, as well as benevolence are the main factors in building trust with others and improving the performance of better management.

Administrators or takmir performance is absolutely necessary to maintain the existence and sustainability of the mosque organization. the Performance Concept has many definitions. Based on $\mathrm{KBBI}$ or the Great Dictionary of the Indonesian Language (KBBI 2021), performance is 1. a goal to be achieved, 2. a noteworthy achievement, 3 . an ability to work. The definition of performance According to Suyadi Prawirosentono (1999) in Arjulis, Edwin Agung Wibowo and Oktavianti (Arjulis, Wibowo, and Oktavianti 2017), was that performance can be interpreted as the result of a person's or group's work that can be achieved based on the authority and responsibility they have so that organizational goals that fit the law, morals and norms can be achieved through various ways of work.

From the definitions of performance above, performance has a broad and varied meaning or definition. Therefore, it can be concluded that performance is a measurable action or task execution in the form of physical and spiritual, for example, activities that are followed by groups or individuals or activities with goals or targets to be achieved by an organization or institution.

One of the important principles used in carrying out management is Good Governance (GG). GG is a procedure in the form of process stages that are supervised, regulated, and balanced by internal and external parties in order to create good and interrelated patterns, systems and structures between the owner and the stakeholders. The existence of strong organizational elements will be able to realize GG and without those elements, it will be difficult to realize GG. There are several principles in GG that need to be applied to conventional agencies consisting of openness, clarity, responsibility, freedom and justice in order to achieve Good Corporate Governance (GCG). (Christian et al. 2018). Based on these principles, an agency or organization is expected to be managed professionally so that it can be driven and developed according to the applicable best practice, rules and norms.

Islamic organizations or institutions have rules to supervise, regulate and harmonize interrelated patterns between the owner and the stakeholders, called Islamic Corporate Governance (ICG). Najmudin (2011) in (Endraswati 2015) stated that Good governance in Islam is a company that is directed and controlled by a system so that the company's goals can be achieved. In other words, the interest and rights of stakeholders can be preserved and protected based on monotheism through basic concepts in making a decision epistemologically, scientifically, and socially in Islam. Besides, (Bhatti and Bhatti 2009) argued that ICG's policies take into account the impact of sharia law, Islamic finance, and economic principles in practice. The welfare of the whole community is the main goal of Islamic Corporate Governance which is based on maqasid shariah (Hasan 2002).

According to Loredana and Roxana, (2016) 4 pillars of Islamic corporate governance include responsibility, accountability, clarity or openness, and accuracy. While the dimensions in taking and determining a decision on the corporate governance in Islam includes with whom; for whom, and with whom and for whom related to mutual.consultation as well as advisory.board.
The principles used in GCG include openness, clarity, responsibility, freedom and justice. Meanwhile, the principles used in the ICG include accountability, responsibility, transparency, and truth. The similarity between the two lies in the three parts of the GG principles, namely accountability, responsibility, transparency, and the differences are independence or freedom and justice in GCG and the principle of truth in ICG.

The management of good governance in an organization does not only lie in good governance but it is also usually caused by poor internal control systems, (M. Sulaiman, Siraj, and Ibrahim 2008; Chenhall, Hall, and Smith 2010; Henri and Journeault 2010). The low supervision for internal control has led to the emergence of budget deviations from religious organizations, Affifudin and Nabihah (2010) and S. Sulaiman et al, (2019) stated that many religious organizations do not have internal control mechanisms to protect their resources and inform members, so that they are aware of the organization's financial status and fundraising activities. M. Sulaiman, Siraj, and Ibrahim (2008) said that managers of an organization need to protect the interests of donors in using and managing financial resources, so that internal systems can be controlled properly.

Said et al.(2013) conveyed that proper internal control will provide better financial performance results and showed that the effectiveness of internal control will improve the programs carried out by the mosque. Good internal control will increase the confidence of donors to provide a number of funds to the organization. Mohamed et al (2014) stated that "management commitment is required to be able to carry out internal control, so that there is a guarantee from the management or organizational management that the donated funds can be accounted properly and correctly".

An important aspect expected to be related to trust and organizational performance is organizational affiliation. This is due to the fact that the majority of the Indonesian population is Muslim, and there are also many socio-religious organizations that have some differences in understanding the concept of sharia. Thus, it is estimated that the influence of this organizational affiliation leads to different management in the mosque organization. As a result of the affiliation of this organization, there is often a clustering of mosques based on the name of a certain organization, Surwandono (2008) even stated that "Affiliation of this organization can create horizontal conflicts among those variedorganizations. There are also many phenomena based on religion issues. For example, $\mathrm{s}$ acts of violence in the name of religion in various regions, as well as the comparison of horizontal conflicts related to religious issues to other horizontal conflicts, and it is considered as a serious intimidation in social harmony.

A mosque as one of non-profit organizations, in which its budget sources come from managing public funds and managing incoming and outgoing organizational budgets, namely contributions from companies, the government, or from the community becomes an interesting organization or institution to study. Financial management originating from government, company and community donations must be properly accounted for. This is where the researcher tried to find out the various variables that could have an impact on the trust and performance of an organization. Therefore, we can find what variable need to be developed to improve the performance of the mosque organization. It is because the higher the level of trust, the better organizational performance, then the number of people praying at the mosque is also getting higher, and eventually the donation received is also higher. 


\section{Literature Review Pecking Order Theory}

\section{Agency theory}

Agency theory was introduced by Jensen and Meckling in 1976 in (Gumanti Ary Tatang 2017) and ( Roziq Ahmad,. and Sumani,. 2020). This theory explains the role of an agent that involves one or more people, as principals, with other agents contractually in the service system through delegation of decision-making authorities to agents. Principals are the participants who participate in capital, while agents are the participants who take part in the workforce and their expertise.

This theory states that principals have less information compared to agents, resulting in inappropriate information. Mwangi, (2012) argued in (Mugi 2018) that this affects the principal's ability to monitor whether or not their interests are well served by the agent. Thus, the theory illustrates that in controlling and reducing the opportunistic actions of agents, the company needs to play an active role in maintaining the agreed contract.

\section{Stakeholder Theory}

Stakeholder theory with the concept of social responsibility was introduced in the early 1970 s, while the stakeholder theory with the concept of management strategy was introduced by Freeman in 1984. Stakeholder theory is a combination of policies and practices related to stakeholders, the need for the rule of law, community and environmental appreciation, values, and the commitment of the business community to participate in sustainable development. R.E. Friedman (1987) argued that stakeholders are several groups or individuals who can influence and be influenced by the achievement of the organization goals.

According to Biset in (Azheri 2012), stakeholders are individuals who have an interest in certain issues. Grimble and Wellard presented stakeholders based on their importance and impact. Meanwhile, Marzully Nur Denies Priantinah (2012) stated that stakeholder theory is a system explicitly based on a point of view related to the organization and the environment by accepting that they affect each other in a dynamic and complex manner. This can be shown from the relationship between the two in social when it is seen from its responsibility and accountability. Therefore, the organization has accountability to stakeholders.

\section{Methodology}

Quantitative approach was used in this research to analyze and test the effects of various variables on the congregation's trust and participation. This was explanatory research, which described the causal relationship of the variables with the hypothesis testing that had been formulated. This research used primary data were, so that the information data obtained were based on the point of view, responses, and evaluations of the mosque organization administrators in Jember Regency, East Java, which were associated with several research variables. Therefore, this research was categorized as a perception research. The population was 156 congregation of all major mosques, namely the Jami' Mosque which was located in Jember Regency, East Java., 156 Sampels were collected using quota purposive sampling technique.

Quantitative analysis included: (1) descriptive analysis based on score mode to reflect sample characteristics; and (2) latent variable analysis used to test hypothesis based on SEM, which was Structural Equation Modeling. Ghozali (2005) argues that SEM is a very important instrument in social science studies, it is because through SEM, the validity and reliability of structural and measurement indicators can be tested together using latent variables.

\section{Results and Discussion}

Data of this research were primary data obtained from questionnaires for organizational management, and 1 respondent was taken from each sample. The submission and collection of questionnaires were carried out directly. There 22 questionnaires distributed and they are all were returned by respondents.

Based on 156 respondents and 22 questionnaires that could be processed, information related to the demographics of respondents was obtained which was used as a benchmark to determine the characteristics of respondents. Based on 34 questionnaires that could be processed, information related to the demographics of respondents was also obtained which was used as a benchmark to determine the characteristics of respondents who were the samples. In this research, the demographics of respondents were based on age, level of education unit, position, length of work, and gender. Based on the demographics of the respondents in table 4.1 above, it can be seen that there were $47.1 \%$ of respondents aged $\geq 40$ years, $52.9 \%$ of respondents were male, $64.7 \%$ of respondents were undergraduates or S1. Based on the position of the respondent, the unit or division manager dominates, namely $58.8 \%$ with a working period of 2 years, which is $55.9 \%$.

This validity test used confirmatory factor analysis on each variable with the AMOS program. If a variable in the indicator has loading factor with a significant $=5 \%$, then it is said to be valid. However, if an instrument has a value of goodness of fit index $(\mathrm{GFI}) \geq 0.90$, then it is categorized as undimensional. Research instruments must be valid and reliable. An instrument is reliable if the results obtained are static or consistent, so that the instrument can be used in different times and situations. So the reliability proves that the measurement results are relatively the same, so it needs repetition in the measurement.

The result of confirmatory factor analysis construct test result is presented in Figure 1 


\section{GENERAL MANAGEMENT}

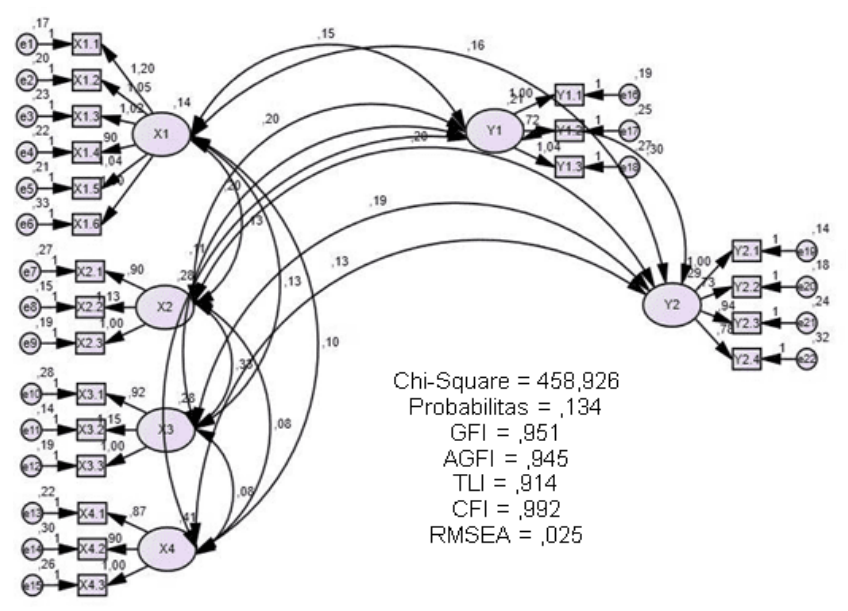

Based on the results of the validity and reliability test with confirmatory factor analysis, it proves that loading factor was above 0.50 . Besides, the probability was below 0.05 , so it can be concluded that all variables are significantly related to the construct. Next, the scores for construct reliability were 0.796 , $0.810,0.911,0.817,0.802,0.728$ and 0.801 . It can be seen that all numbers were higher than the limit value of 0.7 , so it means that all indicators and variables are reliable.

\section{Structural Equation Modeling Analysis}

If the validity, reliability, and normal multivariate assumption tests on the data have been carried out on all indicators and variables in which multicollinearity and outliers do not occur, then the next is a model causality test and a significance test based on the research objective, which is testing the influence of the elements of marketing communication, relationship commitment, on business to consumer relationship quality and customer loyalty of the bakery industry in Jember Regency.

\section{Goodness-of-Fit Test}

The purpose of testing the confirmatory regression model is to determine the conformity of the model to the research shown in table 1. It shows that the model suitability index, namely: CMIN/DF, Chi-square, AGFI, GFI, TLI, CFI, RMSEA in order to measure the feasibility based on the criteria so that the model can be accepted because there is a conformity with the data obtained. The results of the model suitability index are as follows.

\begin{tabular}{lccc}
\hline \multicolumn{1}{c}{ Criteria } & Value of Cutt Off & $\begin{array}{c}\text { Results } \\
\text { Calculation }\end{array}$ & $\begin{array}{c}\text { Informatio } \\
\text { n }\end{array}$ \\
\hline Chi-square & $\begin{array}{c}\text { Expected small ( } \\
\text { X2 with df } 155 \\
\text { is as big as } \\
\end{array}$ & 458,926 & Good \\
& $185,052)$ & & \\
& & & \\
RMSEA & $\leq 0,08$ & 0,025 & Good \\
GFI & $\geq 0,90<1$ & 0,951 & Good \\
AGFI & $\geq 0,90<1$ & 0,945 & Good \\
CMIN/ DF & $\leq 1.0$ atau 3.0 & 2,365 & Good \\
TLI & $\geq 0,90<1$ & 0,914 & Good \\
CFI & $\geq 0,90<1$ & 0,992 & Good \\
\hline
\end{tabular}

Table 1: Goodness of Fit Index

From Table 1, it can be seen that there was only 1 marginal criterion of the 8 criteria used to measure the feasibility, but the suitability of the model is also accepted because the model and data fit each other.

\section{Hypothesis test}

The next stage is testing the causality of the hypothesis against the research model developed. Each path coefficient interprets the suitability of the model which will be detailed in Figure 2 as follows: 


\section{GENERAL MANAGEMENT}

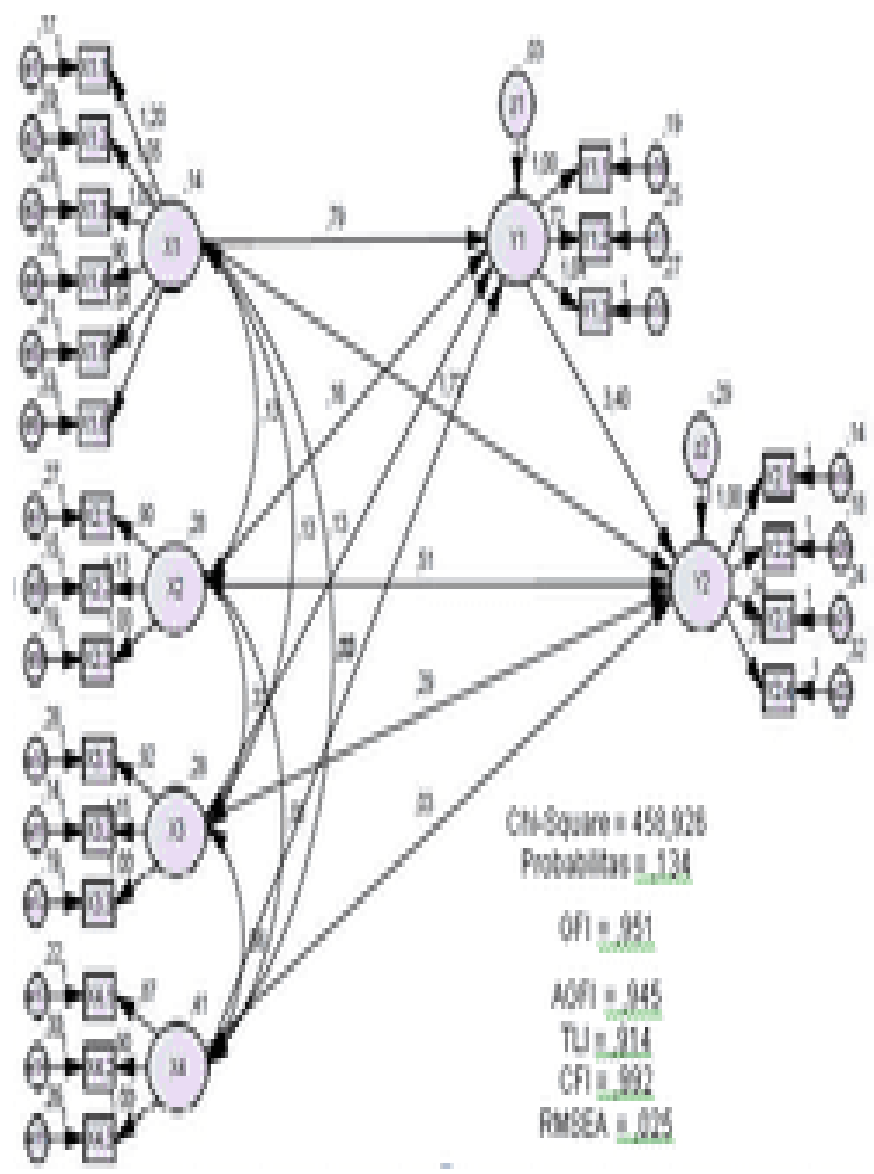

\begin{tabular}{|c|c|c|c|c|c|c|}
\hline \multicolumn{3}{|c|}{ "wht } & $\begin{array}{c}\text { Whith } \\
\text { In } \\
\text { fint }\end{array}$ & P & mity & Whath \\
\hline 4 & 7 & $\mathrm{H}_{1}$ & N4 & $4 x$ & ani & indust \\
\hline 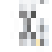 & 4 & $\mathrm{Y}_{1}$ & EII & 274 & and & when \\
\hline I & 7 & Y & 115 & 194 & 141. & ounthet \\
\hline 3 & 4 & Y. & M & in & 17 & whithe \\
\hline$X$ & 7 & Y & 111 & SA & 10 & phu \\
\hline 4 & $\Rightarrow$ & $\mathrm{H}_{1}$ & Ht & yos & fift & 4hw \\
\hline Xi & 7 & $Y_{1}$ & 4 & 47 & 10 & Shban \\
\hline$y$ & 4 & Y & mit & 972 & AII & whis \\
\hline 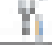 & $\Rightarrow$ & I & Wh & $2 x$ & din & then \\
\hline
\end{tabular}

Table 2: Causality Test Results

Description: significant at $=5 \%$,

Based on the results of testing path coefficient in Table 2 $\mathrm{Y} 1=0.634 \mathrm{X} 1+0.187 \mathrm{X} 2+0.155 \mathrm{X} 3+0.034 \mathrm{X} 4$

$Y 2=1.172 X 1+0.502 X 2+0.290 X 3+0.039 X 4+2,888 Y 1$

\section{Discussion of Test Results}

The results obtained from data processing and testing in the previous discussion provided a lot of additional information regarding the effect of good mosque governance, internal control, service and affiliation of religious organizations on the trust and performance of mosque organizations in Jember Regency. This research provided many benefits and advantages for mosque organizations. Based on the results of data processing and testing carried out, the results of the data processed were displayed based on the formulation of the problem.

Probability and/or critical ratio (CR) needs to be observed in order to determine whether a hypothesis is accepted or rejected with reference if the probability is below 0.05 , meaning that the hypothesis is accepted and there is a significant effect, 
and vice versa.

\section{The effects of good mosque governance (GMG) on the mosque congregation's trust in Jember Regency.}

According to the results of the SEM test, accountability, transparency, independence, justice, responsibility and truth are indicators of good mosque governance (GMG) and according to the results of data testing they have a significant effect on the mosque congregation's trust. Thus the six variable indicators of good mosque governance (GMG (X1) have a significant effect on the congregation's trust (Y1). This is indicated by the significance probability score of the two effects of these variables which was 0.05 or in other words that the error score of this research was still far below the error rate of the research assumption that we used, which was $5 \%$. As for the score of the effects of good mosque governance (GMG) variable on the mosque congregation's trust, according to the test results was 0.634 or $63.4 \%$, with CR of 4.238 and the significance $(p)$ of $0.000<0.05$. It means that the hypothesis is accepted and there is a significant effect. In other words, good mosque governance (GMG) run by the management is able to influence the congregation's trust with the organization's management using quality indicators.

The results of this research also supported O'Neill (2006) in (Heald 2012), Mangoting (2014), Hyndman (2018), Ariany (2017), and Iwan H., Rani R., Maman S. (2018) who argues that, Transparency, accountability, independence, fairness are very important to build trust. Transparency, accountability, independence, fairness are interrelated to provide certainty, which is more than disclosure of providing information that can be accessed and assessed by relevant parties. Good mosque governance (GMG) can be seen as one of the main conditions for improving trust. Good mosque governance (GMG) carried out indicates the form of accountability addressed to the congregation or donors. This is highly necessary to build community's trust and participation.

The use of good mosque governance in the management of the mosque to improve the congregation's trust is crucial, the better the use of good mosque governance in the management of the mosque, the better congregation's trust. The higher the congregation's trust to the management will further increase the congregation's participation in the mosque organization.

\section{Internal control affects the congregation's trust}

The results of this research proved that the hypothesis of internal control according to the results of data testing has a significant effect on the the mosque congregation's trust by $18.7 \%$, or 0.187 , with CR of 2.388 and the significance of $(p)$ $0.017<0.05$. It means that the hypothesis is accepted and there is a significant effect between these variables. In other words, the internal control provided by the management to the congregation or donors to the mosque organization is able to affect the congregation or donors' trust to the organization's management through internal control to build the congregation's trust to the organization's management with quality indicators. The worse the internal control, the lower congregation's trust to the internal control relationship is, and vice versa if it is based on quality indicators.

The results of this research also support Chindy Kurnia Rahma Dewi (2017) on the effect of internal control, compensation alignment, compliance with accounting regulations and non-ethical actions on the tendency of accounting fraud. Internal control also has a significant effect on the tendency of accounting fraud, in the sense that if the effectiveness of the company's internal control increases, the tendency of fraud will certainly decrease, so the alignment of compensation will increase. Disobedience to regulations will increase fraud, and vice versa.

Research conducted by Sofia, YRH (2017), Dewi Novita Wulandari1, Muhammad Nuryatno, 2018 found that internal control has a positive effect on fraud prevention and the internal control system also has a significant relationship in managing finances.

Internal control in non-profit organizations, in this resrach was the mosque organization, where the takmir is an agent who carries out the tasks or mandates that have been given to the congregation as principals. It is necessary to have internal control to control the running of the organization so that it does not go out of the direction and goals of the organization. The better the internal control system, the higher trust level of the congregation is which in turn will increase the organization's income.

\section{Service affects the congregation's trust.}

The results of this research indicated that the service hypothesis, according to the results of data testing, has no significant effect on the mosque congregation's trust with the score of $15.5 \%$, or 0.155 , with CR of 1.947 , and the significance of $(p) 0.000<0.05$. It means that the hypothesis can be accepted and there is a significant effect between these variables. in other words, by looking at the results above, the service hypothesis having an effect on congregation's trust is rejected and there is an insignificant effect, meaning that the services provided by the management to the congregation or donors in the mosque organization are not able to affect the congregation or donors's trust to the organization's management through service to build the congregation's trust to the organization's management with quality indicators.

The results of this research support Kurniawan and Susanto (2017). This is in line with the results of research that prove that patients' trust has an insignificant positive impact if it is based on service quality. Thus, the increased service quality tends to increase patients' trust, although it is not significant. Setyaningsih, Okta (2017) stated increase in loyalty is not directly affected by the quality of service. Based on the results of this research, it proves that customers' loyalty cannot be increased directly when viewed from Saqina.com's service statistics.

\section{The affiliation of religious organizations affects the congregation's trust.}

This research proved that the hypothesis of religious organization affiliation according to the results of data testing has no significant effect on the mosque congregation's trust with the score of $3.4 \%$, or 0.034 , with CR of 0.397 and the significance of $(p) 0.692<0.05$. It means that the hypothesis is rejected and there is an insignificant effect.In other words, by looking at the results above, it proves that the hypothesis is rejected and there is no significant effect. The affiliation of religious organizations given by the management to the congregation or donors to the mosque organization is unable to affect the attitude of trust of the congregation or donors to the organization's management through religious organization affiliation to build the congregation's trust toward the organization's management with quality indicators. The religious organization's affiliation is not significant to the congregation's trust in the organization's management because there is an assumption that the affiliation of religious organizations carried out by the management is a common thing. 


\section{GENERAL MANAGEMENT}

\section{Good mosque governance (GMG) has a significant effect on the mosque organizational performance.}

According to the results of the SEM test, accountability, transparency, independence, justice, responsibility and truth are indicators of good mosque governance (GMG). Based on the results of data testing, those indicators have a significant effect on the mosque congregation's trust. Thus the six variable indicators of good mosque governance (GMG (X1) have a significant effect on the ability of institutional actors (Y1). This is indicated by the significance probability score of the two effects of these variables which was 0.05 or in other words that the error score of this research was still far below the error rate of the research assumption that we use, which was $5 \%$. As for the score of the effects of good mosque governance (GMG) indicators on the performance of mosque organizations, according to the test results, was 1.172 or $117.2 \%$ with CR was 5.421 and the significance was (p) 0.000 $<0.05$. It means that the hypothesis is accepted and there is a significant effect. In other words, good mosque governance (GMG) given by the management to the congregation or donors to the mosque organization is able to affect the organization performance through good mosque governance (GMG) to build organizational performance with quality indicators. The better good mosque governance (GMG), the higher congregation's trust is. Therefore good mosque governance (GMG) has a significant effect on the mosque organizations performance in Jember Regency.

The results of this research also support Nurina Fildjah and Nurdin (2019), Ida Bagus Widya Kirana1 H., Bambang Suprasto, (2019), Ida Ayu Arina Mahadewi, I GAM Asri Dwija Putri (2019) that the organization performance can be improved through good governance that work well together. The active participation of the community or congregation will increase the success of the organization's performance organizers.

Organization performance will continue to increase if good mosque governance (GMG) is adopted properly. Organization performance that goes well will be able to increase congregation participation in mosque organizations. Therefore, good mosque governance (GMG) has a significant effect on the mosque organization performance, the better good mosque governance (GMG), the better the organization performance.

\section{Internal control affects the mosque organization performance.}

This research yielded a hypothesis of internal control that is according to the results of data testing, has a significant effect on the performance of the mosque organization of $50.2 \%$, or 0.502 , with CR of 2.903 and the significance of $(p) 0.004<$ 0.05 . It means that the hypothesis is accepted and there is a significant effect between these variables, meaning that the internal control provided by the management to the congregation or donors to the mosque organization is able to affect the performance of the mosque organization through internal control to build mosque organization performance with quality indicators. The better the internal control, the better the mosque organization performance and the relationship between internal control and quality indicators.

The results of this research also support Tolley Sukma et al (2017), Eke Gift O. (2018), Umar and Dikko (2018) and Said, et al (2013) who stated that the variables of control activities have a significant effect on a person's performance. Internal control has positive relationship with organization performance. These findings made takmir members aware of the importance of improving their performance through strategies in controlling efficient and effective internal systems.

\section{Service has an effect on organization performance.}

This research yielded a service hypothesis that according to the results of data testing, it has a significant effect on the performance of an organization. In other words, if the services provided are improved, the mosque's organization performance will also improve. The relationship between service and quality indicators is in the form of service. According to the results of data testing, it has a significant effect on the performance of the mosque organization of $290.0 \%$, or 0.290 , with CR of 4.741 and the significance of $(p)$ $0.000<0.05$. It means that the hypothesis is accepted and there is a significant effect. In other words, the services provided by the management to the congregation or donors to the mosque organization are able to affect the mosque organization performance. The quality of the services provided to the congregation will affect the performance of an organization.

This research supports and encourages research conducted by Buddy, et al (2019), Kusuma Negara and Wahyu Febrianti (2019), Muhtasom et al (2017) and Maryam Nejadjava and Gilaninia (2016) who stated that service quality has a significant effect on customer satisfaction on the development of the company. Desired organizational targets can be achieved if it is supported by professional organizational management. Manager performance that is one of the most important keys in organizational managemen is service. Excellent service will form a good organizational performance culture, so that it will be strength for the organization in competing with other organizations.

The quality of service provided by takmir will greatly affect organization performance. The maximum service provided to the congregation will affect the congregation participation so that it will directly improve organization performance.

\section{The affiliation of religious organizations has an effect on the performance of the mosque organization.}

The results of the research indicated that the hypothesis of religious organization affiliation, according to the results of data testing, has no significant effect on the performance of the mosque organization, with the score of $3.9 \%$, or 0.039 with CR of 0.215 and the significance of $(p) 0.8300 .05$. It means that the hypothesis is rejected and there is an insignificant effect between these variables. In other words, the affiliation of religious organizations given by the management to the congregation or donors to the mosque organization is unable to affect the performance of the mosque organization through religious organization affiliation to build mosque organizational performance with organizational management with quality indicators.

The results of this research support Setiawan and Lestari (2016) who examined the problem of employees at BPS Bengkulu Province. One of the results of the study is that performance on the culture of an organization does not have a direct significant positive effect, but indirectly has a positive effect based on the commitment variables of an organization. Based on a research conducted by Salbiyah and Mahardhika (2017), the performance of the education staff of UM Surabaya has an insignificant positive effect if it is based on the need for affiliation.

Reasons that organization affiliation had no effect on mosque organizations in Jember Regency were because: 1 . the The takmir was professional in managing the mosque with 
a good understanding of the religion. So that, the congregation did not pay attention to organization affiliation managed by takmir; 2. The education level of the takmir was already high so that it affects the understanding and management of the mosque; 3 . The congregation understands more about the religious differences that exist, not on the subject of religion. 4. Affiliates are needed by everyone, especially today, to build a network by establishing a better organization. In this life, we need to establish realtionship with others, for example, make a friend, involbe get involved in participation in certain groups, and promote cooperation. This should be done to build a better organization.

\section{Congregation's trust affects the performance of the mosque organization.}

The research conducted indicated that the hypothesis of congregation's trust, according to the results of data testing, has a significant effect on organizational performance by $2.2 \%$, or 0.022 , meaning that the better the trust of the congregation, the better the organizational performance of the mosque. Then, the relationship of congregational trust with quality indicators is also better. The results showed that the hypothesis of congregation's trust, according to the results of data testing, has a significant effect on the performance of the mosque organization by $2.2 \%$, or 0.022 with CR of 2.296 and the significance of $(p) 0.000<0.05$, meaning that the hypothesis can be accepted and there was a significant effect. In other words, good congregation's trust in the administrators will improve organizational performance.

Based on this theory, the individual's trust in takmir will affect the intensity of participation in activities organized by the mosque which will directly affect the performance of the mosque organization. Meanwhile, to imporove the trust of the mosque community or congregation to the mosque management, good governance in the mosque must be improved. To create trust in the congregation or the community, it is necessary for the congregation and the community to get involved in the preparation and supervision of programs and activities held by the mosque.

This research also supports Erlan Bakiev (2013), Moh. Mukhsin (2017) and Siti Hajar et al (2018) stating that trust greatly affects organizational performance. The higher the trust, the higher the quality of organizational performance is. Trust is the main factor to improve organizational performance. Trust has a direct or indirect effect on organizational performance.

This research is also in line with the research by Erlan Bakiev (2013), Moh. Mukhsin (2017) and Siti Hajar et al (2018) which stated that trust greatly affects organizational performance. The higher the trust, the higher the quality of organizational performance is. Trust is the main cause for improving organizational performance. Trust affects organizational performance both directly and indirectly.

\section{Conclusion}

Based on the results of analyzing information data, it can be concluded that: 1. Good mosque governance (GMG) variable have a significant effect on the congregation's trust and the performance of the mosque organization and it can be adopted for the organization of the mosque. The results of this resrach support Hardanti Kurniasari Novi and Akbar Muhammad in (2018) and lqzani's study in (2021) about the application of the good governance principles in the mosque organization. 2. The resrach found that internal control has a significant effect on the congregation's trust and the performance of the mosque's organization. The better the internal control, the better its effect on the congregation's trust and the performance of the organization, 3, The service has no significant effect on the congregation's trust. The results of this resrach found that services provided by the takmir cannot increase the congregation's trust in the takmir. 4. The research found that religious organization affiliation has no relevant effect on the congregation's trust and on the performance of the mosque organization. The results of this research found that various organizations adopted by the takmir does not affect the congregation's trust in the takmir and organizational performance. . The results of this research prove that the high level of the congregation's trust to the takmir will certainly increase the performance of the organization.

The level of a good trust can be improved by consinously improving the quality of Good mosque governance using the principles of accountability, transparency, independence, justice, responsibility and truth so that the mosque organization managed can run properly and correctly and the congregation's trust can be achived. Internal control needs to be implemented by increasing expertise, effectiveness, and efficiency in reporting financial statements and maintaining compliance with applicable regulations so that the congregation's trust will continue to increase or the manager of the organization will gain the congregation's trust.

Organization performance can be imporved by improving Good mosque governance implementation using the principles of accountability, transparency, independence, fairness, responsibility and truth. Internal control needs to be implemented by increasing expertise, effectiveness, and efficiency in reporting financial statements and maintaining compliance with applicable regulations, as well as providing oral, written and deed services maximally. When the good mosque governance concept with the principles, internal control and services are used properly, it will be able to improve organization performance.

Congregation's trust in the takmir toimprove the performance of the mosque's organization can be achieved by increasing the ability, kindness and integrity of the takmir. The congregation's trust in the takmir will affect its intensity in participating in activities organized by the mosque, in which it will directly affect the performance of the mosque's organization. The higher the trust, the higher the quality of organizational performance will be. Trust is the main factor to improve organizational performance. Trust has a direct or indirect effect on organizational performance. 


\section{References}

[1] Ahmad Roziq and Sumani. 2020. Mudharaba Financing: Theory, Syar'i and Empirical Studies. 1st ed. Malang: CV. Dream Litera Buana Malang.

[2] Ariany, Vince. 2017. "The Effect of Auditor Independence and Competence on the Quality of Internal Audit at State-Owned Banks in Medan." Owner 1 (1). https://doi.org/10.33395/owner.

[3] Arjulis, Edwin Agung Wibowo, and Oktavianti. 2017. "The Effect of Compensation on Employee Performance at Pt. Djarum Tbk Batam Branch With Work Motivation as Intervening Variable." Jurnal Equilibira 4 (2): 1-24

[4] Azheri, Busyra. 2012. Corporate Social Responsibility; from Voluntary tobe Mandatory,. Edited by Busyra Azheri. Azheri, Bu. Jakarta: Raja Wali Perest.

[5] Bakiev, Erlan. 2013. "The Influence of Interpersonal Trust and Organizational Commitment on Perceived Organizational Performance." Journal of Applied Economics and Business Research 3 (3): 166-80.

[6] Bhatti, M., \& Bhatti, I. (2009). Development in legal Issues of Corporate Governance in Islamic Finance. Journal of Economic and Administrative Sciences, 25(1), 67-91. doi:10.1108/10264116200900004

[7] Buddy, Tabroni, and Fahruddin Salim. 2019. "The Influence of Service Quality and Trust on Customer Satisfaction and Its Impact on Company Reputation (Empirical Study on Umrah and Hajj Travel Companies in East Jakarta)." JOURNAL OF BUSINESS ECONOMICS AND MANAGEMENT VOL 4 NO 2 DECEMBER 2019 E-ISSN: 2597-3902 40.

[8] Chenhall, R. H., Hall, M., \& Smith, D. (2010). Social capital and management control systems: A study of a nongovernment organization. Accounting, Organizations and Society, 35(8), 737-756. doi:10.1016/j.aos.2010.09.006

[9] Christian, Hansen, Wilma Laura, 2018 Business Management Program, Management Studies Program, Petra Christian University, and JI Siwalankerto.. "At Pt. Rofaca Karalmasih Abadi Sidoarjo " 6 (1).

[10] Dewi, Chindy Kurnia Rahma. 2017. "The Effect of Internal Control, Compatibility Compensation, Accounting Compliance and Unethical Behavior on the Trend of Accounting Fraud (Empirical Study on SKPD Bengkalis Regency)." JOM Fekon, Vol. 4 No. 1 (Februari) 20174.

[11] Eke, Gift O. 2018., "Internal Control and Financial Performance of Hospitality Organisations in Rivers State." European Journal of Accounting, Auditing and Finance Research 6 (3): 32-52. www.eajournals.org.

[12] Endraswati, H. (2015). Konsep Awal Islamic Corporate Governance: Peluang Penelitian yang Akan Datang. Muqtasid: Jurnal Ekonomi Dan Perbankan Syariah, 6(2), 89. doi:10.18326/muqtasid.v6i2.89-108

[13] Fildjah, Nurina, and Nurdin. 2019. "The Effect of Good Corporate Governance Implementation and Islamic Social Reporting Disclosures on the Financial Performance of Islamic Banking in Indonesia." Management Proceedings 5 (2): 133338.

[14] Freeman, R.E. 1987. Strategis Managemen: A Stakeholders Approach. Boston: Fitman Boston.

[15] Ghozali, I dan Fuad. 2005. Structural Equation Modeling: Theory, Concepts, and Applications With Lisrel 8.54 Program. Semarang: UNDIP Publishing Agency, Semarang.

[16] Gumanti Ary Tatang. 2017. Corporate Finance Review of Theory And Empirical Evidence. Edited by Gumanti Ary Tatang. 1st ed. Jakarta: Media Wacana Partner Publisher.

[17] Hajar, Siti, A Rahman Lubis, and Permana Honeyta Lubis. 2018. "The Influence of Leadership Behavior and Trust on the Performance of the Social Service, Manpower and Transmigration Office of West Aceh Regency." Journal of Master of Management 2 (1): 46-57.

[18] Haniffa, Sofia Yasmin Roszaini. 2017. "Accountability and Narrative Disclosure by Muslim Charity Organisations in the UK." Journal of Islamic Accounting and Business Research 8:
29.

[19] Hardanti Kurniasari Novi, Akbar Muhammad. 2018. "Phenomeno;Ogy Study on 'Good Mosque Governance': A Case Study of Al Falah Mosque Surabaya Indonesia." Eurasia: Economics \& Business, 12(18), December 2018 DOI Https://Doi.Org/10.18551/Econeurasia.2018-12 10 (1): 27988.

[20] Hasan, Zulkifli. 2002. "Conceptual Definition of Corporate Governance Defining Corporation" Islam Zeitschrift Für Geschichte Und Kultur Des Islamischen Orients, 1-19.

[21] Hassan Basri, Affifuddin, and Siti Nabihah. 2010. "Towards Good Accountability: The Role of Accounting in Islamic Religious Organisations." World Academy of Science, Engineering and Technology, 1133-39.

[22] Heald, D. (2012). Why is transparency about public expenditure so elusive? International Review of Administrative Sciences, 78(1), 30-49. doi:10.1177/0020852311429931

[23] Henri, J.-F., \& Journeault, M. (2010). Eco-control: The influence of management control systems on environmental and economic performance. Accounting, Organizations and Society, 35(1), 63-80. doi:10.1016/j.aos.2009.02.001

[24] Hermansyah, Iwan., Rani Rahman, and Maman Suherman. 2018. "The Effect of Accountability and Transparency on the Quality of Public Services (Survey at the Kotatasikmalaya Regional Office)." Jurnal Akuntansi 13 (1): 21-29.

[25] Hyndman, N., \& McConville, D. (2018). Trust and accountability in UK charities: Exploring the virtuous circle. The British Accounting Review, 50(2), 227-237. doi:10.1016/j.bar.2017.09.004

[26] Iqzani, Elvia Fadjar. 2021. "Implentation of Good Mosque Governance Principles ( Case Study of the Baiturrahman Banyuwangi Grand Mosque )" 6 (1): 253-56.

[27] KBBI. 2021. This Indonesian Dictionary Edited by KBBI Online was developed by Ebta Setiawan (C) 2012-2021 version 2.8. III. Jakarta: KBBI Online was developed by Ebta Setiawan (c) 2012-2021 version 2.8. Copyright Language Development and Development Agency (Language Center). https:/doi.org/https://www.kbbi.web.id/kinerja.

[28] Kirana, Ida Bagus Widya, and H. Bambang Suprasto. 2019. "The Effect of Auditor Independence, Understanding of Good Governance and Self Efficacy on Auditor Performance at KAP Bali. E-Journal of Accounting 27: 1839. https://doi.org/10.24843eja.2019.v27.i03.p08.

[29] Kirana, I. B. W., \& Bambang Suprasto, H. (2019). Pengaruh Independensi Auditor, Pemahaman Good Governance dan Self Efficacy Terhadap Kinerja Auditor Pada KAP Bali. EJurnal Akuntansi, 1839. doi:10.24843/eja.2019.v27.i03.p08

[30] Kusuma Negara, Andi, and Riska Wahyu Febrianti. 2019. "The Influence of Public Service Motivation, Perceived Organizational Support and Organizational Citizenship Behavior on the Performance of Public Sector Organizations in Tangerang City." Dynamic Management Journal 3 (2): 53 64. https://doi.org/10.31000/dmj.v3i2.1962.

[31] Kusuma Negara, A., \& Wahyu Febrianti, R. (2019). PENGARUH MOTIVASI PELAYANAN PUBLIK, PERCEIVED ORGANIZATIONAL SUPPORT DAN ORGANIZATIONAL CITIZENSHIP BEHAVIOR TERHADAP KINERJA ORGANISASI SEKTOR PUBLIK DI KOTA TANGERANG. Dynamic Management Journal, 3(2). doi:10.31000/dmj.v3i2.1962

[32] Maryam Nejadjava, and Shahram Gilaninia. 2016. "The Role of Service Quality in Organizatio." Kuwait Chapter of Arabian Journal of Business and Management Review Vol. 5, No.7, March 20165 (7): 19-27.

[33] Nejadjavad, M., \& Gilaninia, S. (2016). The Role of Service Quality in Organizations. Kuwait Chapter of Arabian Journal of Business and Management Review, 5(7), 19-27. doi:10.12816/0019403

[34] Mohamed, Intan Salwani, Noor Hidayah Ab Aziz, Mohamad Noorman Masrek, and Norzaidi Mohd Daud. 2014. "Mosque Fund Management: Issues on Accountability and Internal 


\section{GENERAL MANAGEMENT}

Controls." Procedia - Social and Behavioral Sciences 145 (August): $189-94$. https://doi.org/10.1016/j.sbspro.2014.06.026.

[35] Mohamed, I. S., Aziz, N. H. A., Masrek, M. N., \& Daud, N. M. (2014). Mosque Fund Management: Issues on Accountability and Internal Controls. Procedia - Social and Behavioral Sciences, 145, 189-194. doi:10.1016/j.sbspro.2014.06.026

[36] Muhtasom, Ali, H Abdul, Rahman Mus, Jamaluddin Bijang, and Baharuddin Latief. 2017. "Influence of Servant Leadership, Organizational Citizenship Bahaviour on Organizational Culture and Employee Performance at Star Hotel in Makassar." International Journal of Education and Research 5 (10): 71-88. www.ijern.com.

[37] Mukhsin, Moh. 2017. "The Effect of Trust and Commitment to the Quality of Relationships in Their Impact on Supply Chain Performance (Case Study of Bran Production and Distribution in Simple PD)." Management Journal 21 (3): 454. https://doi.org/10.24912/jm.v21i3.262.

[38] Munir Is'adi. 2017. "Empowerment and Accountability Report of Jami' Al Baitul Amien Mosque Foundation Jember." Thesis. Jember, East Java.

[39] Nur, Marzully., and Denies Priantinah. 2012. "Analysis of Factors Affecting CSR Disclosures in Indonesia (Empirical Study on Companies with High Profile Category Listed on the Bei)." Nominal Journal I (I): 1-13.

[40] Peraturan pemerintah. 2020. "PP of the Republic of Indonesia Number 21 Year $2 \mathrm{O} 2 \mathrm{O}$ concerning Large-Scale Social Restrictions in the Context of Accelerating Handling Corono Wrus Disease 2019 (COVID-19)" 2019 (022868): 8.

[41] Permata, Elizabeth, and Yenni Mangoting. 2014. "The Effect of Fairness and Communication on Voluntary Compliance Through Trust as Intervining Variables" 4 (1): 1-14.

[42] Said, Jamaliah, Azizah Mohamed, Zuraidah Mohd Sanusi, and Sharifah Norzehan Syed Yusuf. 2013. "Financial Management Practices in Religious Organizations: An Empirical Evidence of Mosque in Malaysia" International Business Research 6 (7): 111-19. https://doi.org/10.5539/ibr.v6n7p111.

[43] Salbiyah, Siti, and Budi Wahyu Mahardhika. 2017. "The Effect of Work Motivation on the Performance of Education Personnel at the University of Muhammadiyah Surabaya in 2016." Balance Journal 14 (2): 1-23

[44] Sanusi, Zuraidah Mohd, Razana Juhaida Johari, Jamaliah Said, and Takiah Iskandar. 2015., "The Effects of Internal
Control System, Financial Management and Accountability of NPOs: The Perspective of Mosques in Malaysia." Procedia Economics and Finance 28 (January 2016): 156-62. https://doi.org/10.1016/s2212-5671(15)01095-3.

[45] Setiawan, Rudi, and Etty Puji Lestari. 2016. "Pengaruh Budaya Organisasi, Komunikasi, Lingkungan Kerja Dan Motivasi Terhadap Komitmen Organisasi Dalam Meningkatkan Kinerja Pegawai." Jurnal Organisasi Dan Manajemen 12 (2): 169-84.

[46] Setyaningsih, Oktania. 2017. "Pengaruh Persepsi Kualitas Pelayanan E-Commerce Terhadap Kepuasan Pelanggan, Kepercayaan Dan Loyalitas Pada Produk Fashion." Jurnal $\begin{array}{llll}\text { Bisnis Dan } & 14 & \text { (2): } 67 .\end{array}$ https://doi.org/10.20961/jbm.v14i2.4126.

[47] Sulaiman, Maliah, Siti Alawiah Siraj, and Shahul Hameed Mohamed Ibrahim. 2008. "Internal Control System in West Malaysia's State Mosques. American Journal of Islamic Social Sciences $\quad 25 \quad$ (1): 63-81. https://doi.org/10.35632/ajiss.v25i1.396.

[48] Sulaiman, Sulaiman, Ahmad Nizam, Farid Farid, Teuku Meldi Kesuma, Iskandarsyah Madjid, and Ridha Siregar. 2019. "The Role of Good Government Governance Principles in Enhancing the Performance of Public Organization in Aceh, Indonesia," no. February 2020. https://doi.org/10.2991/agc18.2019.110.

[49] Suwardono. 2008. "he Dynamics of Islamic Conflict of Islamic Organizations in the Era of Democratization in Yogyakarta." Science, Masters in International Relations, Postgraduate Relations, Faculty of Yogyakarta, University of Muhammadiyah h Tabligh, 11-18.

[50] Tolley, Sukma Selviany, Ridwan Ridwan, and Muh Yunus Kasim. 2017. "The Influence of the Internal Control System for the Regional Apparatus of Sigi Regency." Magister Pascasarjana Universitas Tadulako, Hal.179-190.

[51] Umar, Hussaini, and Muhammed Umar Dikko. 2018. "The Effect of Internal Control on the Performance of Commercial Banks In Nigeria. Accounting 7: 395-400. https://doi.org/10.5267/j.ac.2020.11.012. 